\title{
Analysis on modern apprenticeship status in higher vocational
}

\author{
colleges \\ Shufen Guo ${ }^{1}$,Biqing Li ${ }^{2,}$,, Zhao $\mathrm{Li}^{3}$ \\ ${ }^{1}$ Guangxi Eco-engineering Vocational And Technical College ,Liuzhou Guangxi \\ 545000, China; \\ ${ }^{2}$ College of Mechanical and Electronic Engineering, Hezhou university, Hezhou \\ Guangxi 542899, China; \\ ${ }^{3}$ Management EngineeringDepartment, \\ Guangxi vocational andtechnicalcollege ofcommunications,Liuzhou Guangxi \\ 530000, China; \\ janliful@163.com
}

Abstract.This paper, by means of observation and literature research, comprehensively studies the development of modern apprentice system in higher vocational colleges, aiming to better apply research results to our country's the execution work of modern apprenticeships as guideline. This paper is divided into four parts, and firstly expounds the background of modern apprenticeships. Secondly, expound the status of modern apprenticeship of vocational colleges both at home and abroad, define modern enterprise's technical skills requirement and theoretical knowledge structure requirement. Then enumerate some problems existed in Chinese modern apprenticeship, analyze some practical difficulties existed in modern apprentice system in our country, combined with the existing problems, put forward some opinions and suggestions. Finally, combining the spirit of craftsman recently advocated at home, define the implementation of modern apprenticeship's significance on Chinese Dream. Key words:Higher Vocational Colleges;Modern Apprenticeships; Craftsman Spirit; Countermeasures

\section{Introduction}

Rapid development in social economyand modern vocational educationseriously tendto application technology, the social awareness of apprentice in higher vocational collegesstill presents fragmentation,nowapprentice's recognition in societyis relatively low.Enterprises have higher requirements for employees,not only focuses on the employee's qualifications, professional theory knowledge, the development of personal qualities, etc.,also expects employees to have certain practical experience and technical skills, and expects uniformvalues of employees and enterprise itself.

Observant person may discover, American apprenticeship scheme plays an important role in creating technical talents, the value of the apprenticeship is valued from all levels of society. Apprenticeship promotes cooperation between higher vocational colleges and enterprises, which plays important influence on the talent training plan of global education institutions, western developed countries, such as United States, Germany, Britain, Switzerland, implement apprenticeships, and call for society to 
attach importance to the value of apprenticeships, the apprenticeship in the implementation plays an important role in labor force replacement in the 21 st century. Apprenticeshipscan producesuch important influence today, rather than a miracle, it's an inevitable trend for things to move forward, afterthe commencement of industrial revolution, realistic work requirements between vocational education in colleges and universitiesand enterprise, appear separationphenomenon, academic drift of vocational education, students'due technology practice ability can't be promoted, leading to the apprenticeship's hover in a steadily worsening condition, almost close to the edge of collapse. Now it has become the trump card of personnel cultivating program in vocational college, equal to Starbucks of the service industry, New Oriental of training institutions, a nearly buried education systemchanges into a prominent ace education system of the educational circles.

Apprenticeship has been a hot topic in the reform of higher vocational education from all over the world, since 2012, the pilot apprenticeships has been incorporated into the annual key work. In 2014, Li Keqiang, state council premier, presided over a state council executive meeting, proposed "Ministry of Education's Opinion on modern apprenticeship pilot work", clearly put forward opinions on the teaching docking with the enterprise production, joint training apprentice between higher vocational colleges and enterprises. In the context of the current situation, many domestic vocational colleges carry out pilot practice around the talent training scheme of modern apprenticeship, mainly referring to successful experiences of the developed countries, the United States, Germany, Britain, Switzerland, in dual system, higher vocational colleges and enterprises cooperate, many higher vocational colleges and universities set July to September every year as learning period for the students to practice technical skills in enterprises. Although the implementation of apprenticeship has been paid more attention by national government at present, but there are still many deficiencies in the pilot operation and the plight of reality.

\section{Existing Problems}

(1)Ambiguous Apprentice Positioning

First of all, modern apprenticeship in our country is still in the early stages of a trial, the government lacks enough support on apprenticeships execution in policies, laws and regulations and institution, financial support is relatively low, the apprentice's legal status has not been supplemented.

(2)ImperfectSupervision and Regulation Mechanism

Higher vocational college's teaching combines with the country's top design, with unique professional training program and supervision mechanism as the supplement. Currently,Chinese apprenticeships implementation lacks perfect mechanism of supervision and regulation,trial work can't be properly protected.From the point of enterprise, enterprises can't get many projects supported by government policy, enterprises' enthusiasm is not high, so the apprentice can't get a good technical practice platform.Looked from the perspective of school,schools think that the work has been done after sending students to the enterprise for practice, lack enough care for the students' practice,higher vocational colleges lacks close cooperation with enterprises, 
and technology theory and practice of students is difficult to integrate.

(3)Lower Social Awareness of Apprenticeships

Learning from the successful experience of apprenticeship development of developed country, the plan implementation of a country tends to have close relationship with mass media dynamics, the broad masses are deeply affected by the traditional education concept in our country, most of the public think education 's point is theory, not applications, in the traditional sense, apprentice is regarded as a symbol of low social status. And the general public lacks relative identity for apprentice, the identity of the apprentice can't get recognition of the students and parents fundamentally, leading to that students have little enthusiasm to involve in the plan implementation of the apprenticeship. Enterprises have less enthusiasm for its participation in its modern apprenticeship, enterprise's social consciousness and social responsibility is not strong, don't consider participation in the modern apprenticeship and training innovative skilled workforce in the 21 st century, as the enterprise's responsibility and mission.

\section{Suggestion}

Recently, spirit of craftsmanship and modern apprenticeship has been the hot topic in Chinese top work, spirit of craftsmanship is pure performance of social consciousness in study and work practice, school as an independent theory education location, while guiding students to learn theoretical knowledge, also develop students' consciousness of the spirit of craftsman, such apprentice devote themselves to the practical work of the enterprise, liquidity of "finishing apprenticeship" is not frequent, which virtually guarantees enterprises in terms of talent demand. Modern apprenticeship has brought new vitality to higher vocational education, also injected new hope to Chinese industry, so we should do well mass communication, acquaint the broader social public and understand the importance of modern apprenticeships. To perfect modern apprenticeship also needs constant efforts, constant innovation, combining the theory and the actual conditions of China, assess institutionalization of modern apprenticeship, normalize apprentice's education assessment, so that the apprenticeship can play biggest positive impact role, train more high-level technical application talents for the country's industry, lay solid talent base for national industry. The reform of higher vocational educationbrings opportunity to the development of modern apprenticeship, beneficial to build scientific application technical power, and create high skilled talents,making high-tech become public faith. To implement modern apprenticeship in higher vocational colleges, must endow unique values on modern apprentice,let the public believe in science and technology, then science and technology will have a soul,to achieve spiritual communication with the country's top design.

\section{Conclusion}

In the import function of intellectual property management, as the corresponding items and required ones are selected in the drop-draw list, the mouse cursor shall be put in the corresponding position of the required item to reduce the users' workload and then reduce the error probability. 
This work is supported the following fund :

2016 The project of improving the basic ability of young teachers in Colleges and universities in Guangxi:"Design and development of electronic commerce platform of agricultural products based on Semantic Technology"(No,KY2016YB455).

2015 college students' innovative training program: "Research on the application of value added travel experience in the mobile terminal of the 'ethnic custom travel' in Guangxi" (No 201511838070);\&\& “The design and development HeYuanTong Campus Mobile Phone APP based on Android" (No 201511838034).

2015 Teaching case project construction project of hezhou university: "Tourist positioning and guiding system project of Huangyao scenic";\&\& "Development and application of the information management system of 'Huang Yao Tong'".

Project of scientific research and technology development project of Hezhou: "Design and implementation of agricultural products e-commerce platform based on Semantic Technology" (No,Hekeneng 1506006)

Scientific research project of hezhou university:"Research and development of E-government platform based on mobile terminal" (No 2015ZZZK03);

Reform in Education project of hezhou university: "Internet of things"(No hzxytszy201501); "Research on application personnel training model of Communications for SMEs"(No hzxyjg201525);

Master degree discipline construction scientific research and Cultivation Project: "Research on the social work service of the teenagers' Network Addiction"(No 2015SHGZ005) \&\&"Research on the intelligent development of rural tourism in Guangxi based on the Internet of things" (No 2015MTA16);

\section{Reference}

[1]B.QLI,Y.F LING,H.YZHANG,S.Y ZHENG:The Design and Realization of Cherry Tomato Harvesting Robot Based on IOT.International Journal of Online Engineering,12(12),23, (2016).

[2]B.QLI,W.LGUAN,S.Y Zheng,X.G Yue: OPTIMISATION DESIGN OF CORN PRECISION SEEDER BASED ON MULTI-ROUTE AND MULTI-CHANNEL CONTROL. JOURNAL OF THE BALKAN TRIBOLOGICAL ASSOCIATION,21(4A),1215,(2015).

[3]Zheng SG, Weili; Li, Biqing: Social Work in Teen Addiction Correction Services Research Under the New Situation. In: Wang JX, P, editor. 4th National Conference on Electrical, Electronics and Computer Engineering (NCEECE); Xian, PEOPLES R CHINA: ATLANTIS PRESS; 2016. p. 252-5.

[4]Zheng SG, WL; Li, BQ: Digital Display Design of Ethnic Clothing of Nanling. In: Liang ZL, X, editor. 4th International Conference on Mechatronics, Materials, Chemistry and Computer Engineering (ICMMCCE); Xian, PEOPLES R CHINA: ATLANTIS PRESS; 2015. p. 2805-8. 